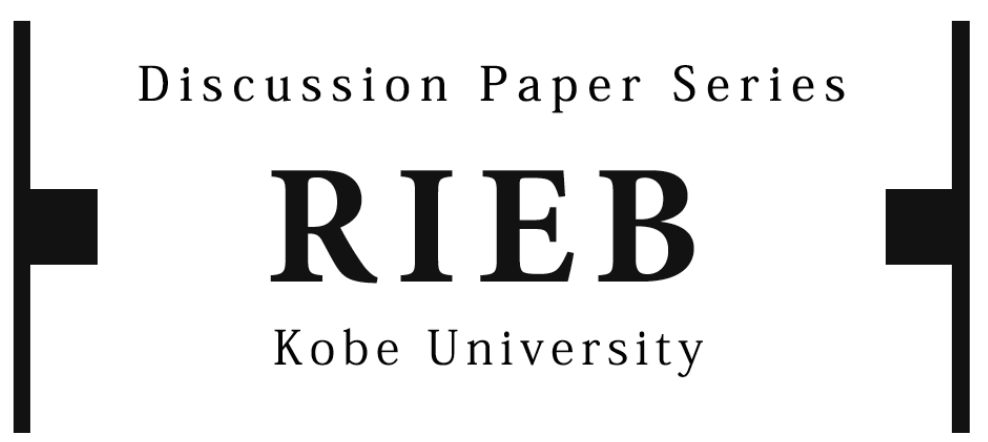

DP2012-01

Productivity and Openness:

Firm Level Evidence in Brazilian Manufacturing Industries

\author{
Wenjun LIU \\ Shoji NISHIJIMA
}

January 17, 2012

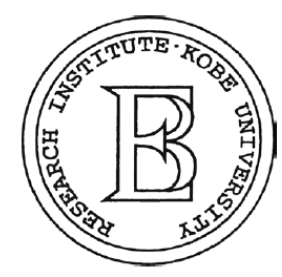

Research Institute for Economics and Business Administration Kobe University 


\title{
Productivity and openness:
}

\section{firm level evidence in Brazilian manufacturing industries}

\author{
Wenjun Liu ${ }^{\mathrm{a}}$ \\ Shoji Nishijimab \\ ${ }^{a}$ College of Economics and Management, Univ. of South China \\ Hengyang, Hunan Province, China \\ ${ }^{\mathrm{b}}$ Research Institute for Economics and Business Administration, \\ Kobe University, Nada-ku, Kobe, Japan \\ January 17,2012
}

\begin{abstract}
This study investigates the productivity of Brazilian manufacturing industries, particularly addressing the influence of liberalization on productivity. We first calculate total factor productivity (TFP) by estimating the stochastic frontier production function and the inefficiency determination equation simultaneously. Then TFP growth rates are regressed on openness-related variables and other firm characteristics. The results show that firm openness to the world is a crucial determinant of their productivity. Data used for this study were obtained from the Investment Climate Survey, provided by the World Bank.
\end{abstract}

JEL Classification: D22, O12, O54

Keywords: TFP, liberalization, Brazil, stochastic frontier analysis

Corresponding author: E-mail: nishijima@rieb.kobe-u.ac.jp

Acknowledgements: We would like to thank the World Bank Group for allowing us to have access to the data used in this paper. All the analysis, interpretations and conclusions drawn from the data in this paper are entirely and solely those of ours. 


\section{Introduction}

In Brazil, following tariff reductions of the late 1980s, full-scale economic liberalization began in 1990 under the Collor government. Dramatic shifts in development policies from government intervention to market mechanisms enhanced various economic liberalization efforts very rapidly in areas such as trade liberalization, capital account liberalization, privatization, capital market liberalization and deregulation. In 1994, Brazil's persistent high inflation was suppressed by the introduction of the Real Plan, which restored the functions of price mechanisms and subsequently brought new dynamism to the Brazilian economy. Despite its financial crisis of 1999, Brazil was able to continue favourable economic performance in the 2000s because of strong global demand for natural resources and because of the expansion of domestic demand.

However, to achieve long-term sustainable growth, Brazil now confronts various challenges. In macroeconomic terms, the following are particularly important: low domestic savings, concentrated income distribution and extreme poverty, insufficient infrastructure, inefficient financial intermediation, inadequate education systems and ineffective and inefficient institutions. Regarding microeconomic issues, it is imperative for Brazil to improve efficiency and productivity at the firm and industry level. Without overcoming these challenges, Brazil will not be able to secure long-term growth.

As described in this paper, we investigate the productivity of Brazilian manufacturing firms, particularly addressing the relation between productivity and openness. We first calculate total factor productivity (TFP) using stochastic frontier analysis (SFA). Then we examine the TFP determinants. Section 2 surveys the literature on the relation between trade liberalization and productivity in Brazil. Section 3 introduces SFA. Section 4 estimates the stochastic frontier production function and the inefficiency determination equation simultaneously to derive TFP growth rates consistently. In Section 5, regression analyses are conducted to estimate the determinants of TFP growth rates. Our hypothesis is that firms' openness to the world is a crucial determinant of their productivity. The final section is reserved for concluding remarks. Data used for this study were obtained from the Investment Climate Survey, provided by the World Bank.

\section{Literature survey of productivity in Brazil}

The reasons for increased productivity attributable to trade liberalization can be regarded theoretically as follows.

(1) Correction of failures of resource allocation under protective policies:

Trade liberalization stimulates the reallocation of productive resources from low-productivity industries (or sectors) to those with high productivity, which is expected to improve macroeconomic productivity. Generally, resource reallocation occurs through exit or contraction of low-productivity firms and/or entry or expansion 
of high-productivity firms.

(2) Promotion of technological progress:

Trade liberalization increases capital good and intermediate good imports, which embody advanced foreign technologies. Similarly, foreign direct investment will induce technology transfers and promote $\mathrm{R} \& \mathrm{D}$ activities, which are expected to improve the overall level of technology of domestic industries and firms.

(3) Increase of production efficiency:

Confronting increased pressure from import competition is expected to accelerate productive and managerial improvements to survive or maintain market share, which will engender increased production efficiency.

Fig. 1 depicts the three points above using a production possibility frontier. Technological progress is expressed as an outward shift of the production frontier. Movement from point A to $\mathrm{B}$ represents improvement of production efficiency. Improvement of resource allocation is described as a movement from point $\mathrm{B}$ to point $\mathrm{C}$.

Figure 1 Three modes of productivity change

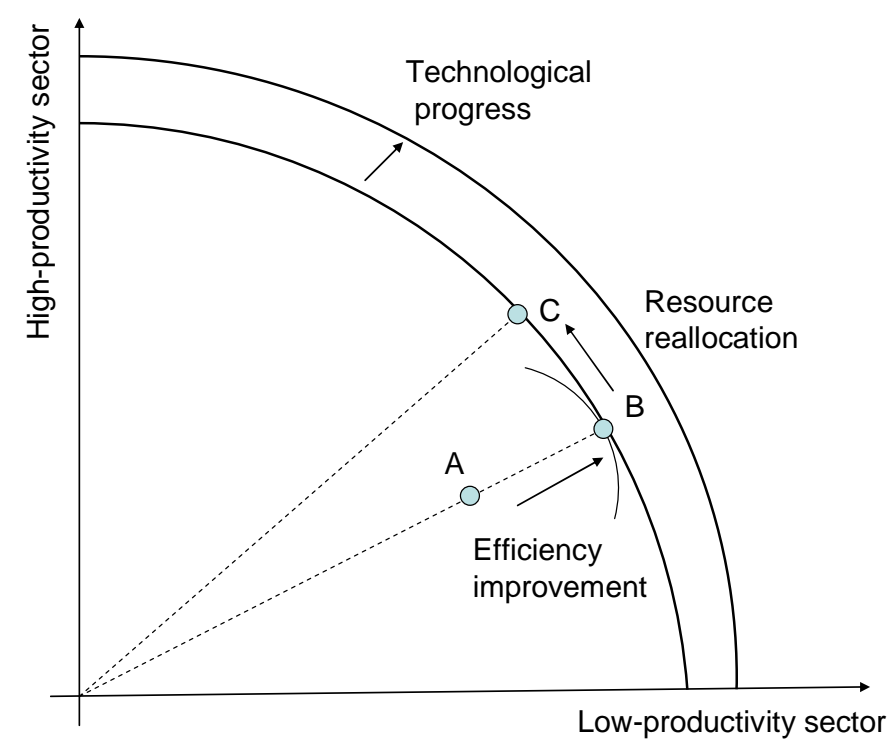

Source: Muendler(2003)

Brazil's average tariff rate was maintained at more than $50 \%$ until 1987 , but a drastic tariff reduction was undertaken in 1988 . The average rate was reduced to $12 \%$ in 1995 . Previous studies have mainly examined the effects of tariff reduction that occurred in the 1980s and 1990s. A representative study by Ferreira et al. (2003) discussed the TFP calculated by estimating a production function using a panel data with 16 industries from 1985 to 1997. Results show that although the average TFP growth rates among industries were negative in the 1980s, they became positive in the 1990s. Tariff reduction had a significant influence on these improved TFP growth rates, although the import ratio had no significant relation. 
Hay (2001a), using data of 318 large firms from 1986 through 1994 provided by Pesquisa Industrial Annual (PIA: IBGE), investigated the effects of trade liberalization on market share, profits and efficiency. The TFP were obtained by estimating a Cobb-Douglas type production function. Hay concluded that the TFP improvements from 1990 were attributable to various factors such as tariff reduction, changes in management, technological improvements induced by imported capital goods and intermediate inputs, increased market competition, foreign direct investment and increased exit of inefficient firms. Hay (2001b) and Rossi et al. (1999) derived the conclusion that reduction of tariffs and of non-tariff barriers in the 1990s contributed to the improvement of TFP growth and of labour productivity in Brazil. Through empirical studies using the PIA's firm-level data, Muendler (2004) argued that imported inputs had limited impacts on productivity, although competitive pressures from abroad and the probability of bankruptcy had significant impacts on productivity.

Studies of the technical efficiency of Brazilian manufacturing industries based on SFA have been very limited to date, but Nazmi et al. (2008) investigated technical efficiency in Brazil, China and India by estimating the macro production frontiers of the three countries using a panel data from 1980 to 2006 . The study concludes that the three countries tended to improve their efficiency and that Brazil's efficiency was lower than that of either China or India. Regarding the determinants of technical efficiency, structural variables such as government size (government consumption vs. GDP), openness (exports and imports vs. GDP) and international competitiveness (real exchange rate) showed significant influences. In contrast, Constantin et al. (2009) estimated the technical efficiency of five agricultural sectors in Brazil, but did not consider the effects of trade liberalization.

Based on the data from the Investment Climate Surveys provided by the World Bank, Subramanian et al. (2005) analysed the effects of different variables on TFP in China and Brazil. TFP is regressed on variables for investment climates and firms' characteristics. Regarding investment climates, the availability of skilled labour, condition of public goods, efficiency of regulation and bureaucracy, transportation costs and market competition are all considered. The study revealed that delays of customs procedures and the use of email had significant effects on firm's TFP in both countries. Regarding firm characteristics, the dummy variable for state enterprise is negative and significant in China. Years of education and instability of electrical supplies have significant and negative impacts in Brazil. Nishijima (2009) calculated the TFP index introduced by Caves et al. (1982) and elaborated by Aw (2001) and Good et al. (1997) ${ }^{1}$. Using this TFP index, Nishijima (2009) investigated the effects of openness on productivity and found that the exporter variable and industrial dummy that represents the degree of tariff reduction of each industry had positive effects on TFP, while the ratio of imported inputs and foreign capital participation did not have significant effects. Regarding the business environment, the instability of electricity, labour disputes and limited credit access showed significant negative effects on TFP.

\footnotetext{
${ }^{1}$ The TFP index is the relative productivity of each firm compared to the industry-average TFP.
} 
In light of previous studies, we investigated the relation between trade liberalization and productivity with the following specific objectives.

(1) In addition to the effect of direct trade policy changes such as tariff reductions, we will specifically examine factors related to firm openness: export orientation, import competition, imported capital goods and intermediate goods and FDI.

(2) Although many previous studies have calculated TFP through estimation of a production function at the macro level and industry level, we will estimate TFP using firm-level data based on SFA. Then we will analyse the determinant factors for TFP.

\section{Methodology for SFA}

The first discussions of SFA were presented in three papers by Meeusen and van den Broeck (1977), Aigner, Lovell and Schmidt (1977) and Battese and Corra (1977). These three original SFA models had the same feature: a shared error term that comprises a symmetric random error and a non-negative technical inefficiency term (Kumbhakar and Lovell, 2003). Although early studies did not explicitly formulate a model for these technical inefficiency effects in terms of appropriate explanatory variables, some empirical papers such as those of Pitt and Lee (1981) and Kalirajan (1981) presented a two-stage approach in which the first stage involves the specification and estimation of the stochastic frontier production function and the prediction of the technical inefficiency effects, under the assumption that these inefficiency effects are distributed identically. The second stage involves the specification of a regression model for the predicted technical inefficiency effects. Nevertheless, the disadvantage of the two-stage approach is that the regression in the second stage contradicts the assumption of identically distributed inefficiency effects in the stochastic frontier. To address this problem, Battese and Coelli (1995) proposed a one-stage approach for panel data so that the parameters of the stochastic frontier and the inefficiency model are estimated simultaneously.

Mathematically, it can be expressed as follows.

$$
Y_{i t}=F\left(X_{i t}, \beta, t\right) e^{V_{i t}-U_{i t}}, \quad i=1,2, \ldots, N, \quad t=1,2, \ldots, T
$$

where $Y_{i t}$ denotes the output for firm $i$ at period $t ; X_{i}$ denotes a vector of inputs of production for firm $i$ at period $t ; \beta$ is a vector of unknown parameters to be estimated; $V_{i t}$ is assumed to be distributed identically and independently as $N\left(0, \sigma_{v}^{2}\right) ; U_{i t}$, which is independent of $V_{i t}$, is

defined by the truncation (at zero) of $N\left(Z_{i t} \delta, \sigma_{u}^{2}\right)$ distributions, where $U_{i t}$ is an inefficiency term of production. In addition, $Z_{i t}$ signifies a vector of explanatory variables associated with technical inefficiency of production of firms over time, and $\delta$ denotes a vector of unknown coefficients.

The technical inefficiency effect, $U_{i t}$, in the stochastic frontier model (1) is specified in Equation (2) as follows. 


$$
U_{i t}=z_{i t} \delta+w_{i t}
$$

Therein, random variable $w_{i t}$ is defined by the truncation of the normal distribution with zero mean and variance, $\sigma^{2}$. These assumptions are consistent with $U_{i t}$ being a non-negative truncation of the $N\left(Z_{i t} \delta, \sigma^{2}\right)$ distribution. The technical efficiency of production for firm $i$ at period $t$ is defined by Equation (3) as presented below.

$$
T E_{i t}=\exp \left(-U_{i t}\right)=\exp \left(-z_{i t} \delta-w_{i t}\right)
$$

Battese and Coelli (1995) proposed a maximum likelihood method for simultaneous estimation of the parameters of the stochastic frontier and a model for the technical inefficiency effects. The likelihood function is expressed in terms of the variance parameters.

$$
\sigma^{2} \equiv \sigma_{v}^{2}+\sigma_{u}^{2}, \quad \gamma \equiv \sigma_{u}^{2} / \sigma^{2}
$$

The partial derivatives of the logarithm of Equation (1) with respect to time $t$ give the following.

$$
\frac{\dot{Y}_{i t}}{Y_{i t}}=\left(e_{f / x} \cdot \frac{\dot{X}_{i t}}{X_{i t}}+\dot{v}_{i t}\right)+e_{f / t}-\dot{u}_{i t}
$$

In that equation, $e_{f / x}$ and $e_{f / t}$ respectively denote the output elasticities of $F\left(X_{i t}, \beta, t\right)$

with respect to $X_{i t}$ and $t$. Dotted variables show time derivatives.

As shown by Equation (4), output changes can be decomposed into three components. The first one corresponds to input changes weighted by output elasticities. Because $v_{i t}$ is distributed as $N\left(0, \sigma_{v}^{2}\right)$, the effect of the random error $\dot{v}_{i t}$ is equal to zero. It can be ignored.

$e_{f / t}$ denotes the rate of technological change corresponding to the shifts of the frontier and $-\dot{u}_{i t}$ represents the technical efficiency change. Therefore, the rate of total productivity change is the sum of the last two components: $e_{f / t}$ and $-\dot{u}_{i t}$. Following Coelli et al. (2005), the technological change (TC) index between the adjacent periods is calculated as the geometric mean of two partial derivatives.

$$
T C=\exp \left\{\frac{1}{2}\left(e_{f / t}+e_{f / t-1}\right)\right\}
$$

The technical efficiency change (TEC) index is defined as shown below. 


$$
T E C=T E_{i t} / T E_{i t-1}
$$

The Malmquist TFP index, which implies TFP changes (TFPC), is obtainable by multiplying TC by TEC ${ }^{2}$.

$$
\text { MalmquistTFP }=T C \times T E C=T F P C
$$

In the following section, we estimate the stochastic frontier function and the inefficiency equation simultaneously. Then, using the results of the estimations, we calculate the TFPC.

\section{Estimation of Stochastic Frontier Production Function and Inefficiency Equation}

The Investment Climate Survey uses standardized survey instruments and a uniform sampling methodology to analyze firm performance and the business environment of most developing countries. The survey of Brazil 2003 includes 1640 observations in the manufacturing sector during 2000-2002. Data were collected from nine industries: Food processing, Textiles, Apparel, Shoes and leather products, Chemicals, Machinery, Electronics, Auto parts and Furniture. Geographically it covers 13 states: São Paulo, Rio de Janeiro, Minas Gerais, Santa Catarina, Rio Grande do Sul, Paraná, Goiás, Mato Grosso, Ceará, Paraíba, Maranhão, Bahia and Amazonas.

The translog stochastic frontier production function (8) is assumed to represent the production technology of the firms in Brazilian manufacturing industry. Technical inefficiency is calculated as shown in Equation (8).

$$
\begin{aligned}
y_{i t}= & \beta_{0}+\sum_{m=1}^{4} \beta_{m} x_{m i t}+\sum_{m=1}^{4} \sum_{k \geq m}^{4} \beta_{m k} x_{m i t} x_{k i t}+\beta_{t} \tau+\beta_{t t} \tau^{2} \\
& +\sum_{m=1}^{4} \beta_{t m} \tau x_{m i t}+V_{i}-U_{i} \quad i=1,2, \ldots, N \quad t=1,2,3 \ldots \\
U_{i t}= & \delta_{0}+\sum_{n=1}^{18} \delta_{n} z_{n i t}+w_{i t}, \quad n=1,2, \ldots, 18
\end{aligned}
$$

In those equations, $y_{i t}$ denotes the natural logarithm of the total market value of production for firm $i$ (in R $\$$ ) in period $t$. To calculate the real output value, the wholesale price index (IGP-DI) of each industry is used. $x_{\text {mit }}$ denotes the natural logarithm of input $m$ for firm $i$ at period $t$. In our empirical study, inputs of four types are considered: $x_{1 i t}$ is the direct cost of raw materials (in $\mathrm{R} \$$ ) deflated by the price index of intermediate goods; $x_{2 i t}$ is total energy cost (in $\mathrm{R} \$$ ) deflated by the energy price index; $x_{3 i t}$ is the total number of full-time workers; $x_{4 i t}$ is the real capital stock (in R\$) calculated using the cumulative sequential addition of new investment to the base year capital stock (perpetual inventory method). The base year capital stock was

\footnotetext{
${ }^{2}$ The Malmquist TFP index was defined as the geometric mean of two distance indices, which was introduced by Caves et al. (1982) after Sten Malmquist, who earlier proposed construction of quantity indexes as ratios of distance functions.
} 
obtained from the net book value of fixed assets by excluding depreciation.

$$
K_{t}=K_{t-1}+I_{t}
$$

In that equation, $K_{t}$ denotes real capital stock and $I_{t}$ denotes investments made during period $t$. Investment was deflated by the investment goods price in period $t$. The remaining variables and parameters are the following: $\tau$ stands for a time trend representing technological change; $z_{n i t}$ represents variables of firm characteristics that presumably influence technical efficiency; $\beta_{\mathrm{s}}$ and $\delta_{\mathrm{s}}$ signify unknown parameters to be estimated; and the $V_{i t}, U_{i t}, W_{i t}$ are as defined in the previous section. Table 1 presents descriptive statistics of the variables.

Table 1. Description and summary statistics of variables

\begin{tabular}{|c|c|c|c|c|c|c|c|}
\hline Variables & Symbol & Description & Mean & St. Dev. & Min & Max & $\begin{array}{l}\text { Number } \\
\text { of obs. }\end{array}$ \\
\hline \multicolumn{8}{|c|}{ Stochastic frontier function } \\
\hline Total output & $y_{i t}$ & Natural logarithm of the total market value of production (in $\mathrm{R} \$$ ) & 14.566 & 1.985 & 6.368 & 22.110 & 4564 \\
\hline Material & $x_{1 i t}$ & $\begin{array}{l}\text { Natural logarithm of the direct cost of raw materials and inputs (in } \\
\mathrm{R} \$ \text { ) }\end{array}$ & 13.507 & 2.162 & 7.356 & 21.232 & 4443 \\
\hline Energy & $x_{2 i t}$ & Natural logarithm of the total energy costs (in $\mathrm{R} \$$ ) & 10.225 & 2.028 & 0.405 & 18.391 & 4566 \\
\hline Labour & $x_{3 i t}$ & Natural logarithm of the total number of full-time workers & 3.961 & 1.137 & 0.000 & 8.772 & 4800 \\
\hline Capital & $x_{4 i t}$ & $\begin{array}{l}\text { Natural logarithm of the real capital stock, constructed by net book } \\
\text { value of fixed assets (in } \mathrm{R} \$ \text { ) }\end{array}$ & 12.968 & 2.299 & 4.997 & 20.633 & 4342 \\
\hline \multicolumn{8}{|c|}{ Efficiency determination function } \\
\hline \multicolumn{8}{|c|}{ Industry dummy } \\
\hline Food processing & $z_{0 i t}$ & $\begin{array}{l}1 \text { for firms of the food processing industry, and } 0 \text { otherwise (base } \\
\text { groun) }\end{array}$ & 0.077 & 0.267 & 0 & 1 & 4920 \\
\hline Textiles & $z_{1 i t}$ & 1 for firms of the Textiles industry, and 0 otherwise & 0.065 & 0.246 & 0 & 1 & 4920 \\
\hline Garments & $z_{2 i t}$ & 1 for firms of the Garments industry, and 0 otherwise & 0.270 & 0.444 & 0 & 1 & 4920 \\
\hline Shoes and Leather & $z_{3 i t}$ & $\begin{array}{l}1 \text { for firms of the Shoes and Leather Products industry, and } 0 \\
\text { otherwise }\end{array}$ & 0.105 & 0.307 & 0 & 1 & 4920 \\
\hline Chemicals & $z_{4 i t}$ & 1 for firms of the Chemicals industry, and 0 otherwise & 0.051 & 0.220 & 0 & 1 & 4920 \\
\hline Machinery & $z_{5 i t}$ & 1 for firms of the Machinery industry, and 0 otherwise & 0.112 & 0.315 & 0 & 1 & 4920 \\
\hline Electronics & $z_{6 i t}$ & 1 for firms of the Electronics industry, and 0 otherwise & 0.048 & 0.214 & 0 & 1 & 4920 \\
\hline Auto-parts & $z_{7 i t}$ & 1 for firms of the Auto-parts industry, and 0 otherwise & 0.079 & 0.270 & 0 & 1 & 4920 \\
\hline Furniture & $z_{8 i t}$ & 1 for firms of the Furniture industry, and 0 otherwise & 0.192 & 0.394 & 0 & 1 & 4920 \\
\hline $\begin{array}{l}\text { Education level of } \\
\text { principal manager }\end{array}$ & $z_{9 i t}$ & $\begin{array}{l}\text { Ranked from } 1 \text { to } 8 \text { where } 1 \text { is the highest level (post graduate } \\
\text { degree), and } 8 \text { is the lowest level (did not complete primary school) }\end{array}$ & 3.126 & 1.944 & 1 & 8 & 4914 \\
\hline $\begin{array}{l}\text { Working experience of } \\
\text { principal manager }\end{array}$ & $z_{10 i t}$ & Working years in the same industry & 19.512 & 11.637 & 0.04 & 78 & 4911 \\
\hline Foreign competitor & $z_{11 i t}$ & $\begin{array}{l}\text { Dummy variable equal to } 1 \text { for firms mainly competing with } \\
\text { imported products, and } 0 \text { otherwise }\end{array}$ & 0.136 & 0.343 & 0 & 1 & 4869 \\
\hline Telephone & $z_{12 i t}$ & $\begin{array}{l}\text { Ranked from } 1 \text { to } 5 \text { where } 1 \text { is most using telephones for } \\
\text { communication, and } 5 \text { is less used, and } 9 \text { is not used }\end{array}$ & 1.201 & 0.584 & 1 & 9 & 4920 \\
\hline Internet & $z_{13 i t}$ & $\begin{array}{l}\text { Ranked from } 1 \text { to } 5 \text { where } 1 \text { most uses the internet for } \\
\text { communication, and } 5 \text { is less used, and } 9 \text { is not used }\end{array}$ & 5.674 & 2.160 & 1 & 9 & 4920 \\
\hline Computer & $z_{14 i t}$ & $\begin{array}{l}\text { The share of total workforce of the firm regularly using a computer } \\
\text { for tasks }\end{array}$ & 17.497 & 17.484 & 0 & 100 & 4908 \\
\hline Loan & $z_{15 i t}$ & $\begin{array}{l}\text { Dummy variable that equals } 1 \text { for firms with loan from a bank or } \\
\text { financial institution, and } 0 \text { otherwise }\end{array}$ & 0.175 & 0.380 & 0 & 1 & 4920 \\
\hline Export & $z_{16 i t}$ & $\begin{array}{l}\text { Dummy variable that equals } 1 \text { for firms exporting products, and } 0 \\
\text { otherwise }\end{array}$ & 0.310 & 0.463 & 0 & 1 & 4920 \\
\hline Capital import & $z_{17 i t}$ & $\begin{array}{l}\text { Dummy variable that equals } 1 \text { for firms importing machinery or } \\
\text { equipment, and } 0 \text { otherwise }\end{array}$ & 0.100 & 0.300 & 0 & 1 & 4920 \\
\hline Technology advantage & $z_{18 i t}$ & $\begin{array}{l}\text { Ranked from } 1 \text { to } 3 \text {, where } 1 \text { means that the firm's technology is } \\
\text { less advanced than that of its main competitor, } 2 \text { means the same, } \\
\text { and } 3 \text { means more advanced. }\end{array}$ & 2.082 & 0.619 & 1 & 3 & 4911 \\
\hline
\end{tabular}

Note: Observations with missing values are excluded from the number of observations. The final sample for frontier estimate has 4032 observations after we deleted missing values and kept the panel balanced. 
The stochastic frontier production function was fitted by maximum-likelihood estimation using the FRONTIER 4.1 program (Coelli, 1996). The null hypothesis, that the Cobb-Douglas production function is an adequate representation $\left(\beta_{m k}=\beta_{t t}=\beta_{t m}=0\right)$ of our sample, was rejected by generalized likelihood ratio tests (see Table 2). A likelihood ratio test was also used to select the functional form between the full translog form and the translog with neutral technological change $\left(\beta_{t m}=0\right)$. The results suggest that the translog form is suitable for our empirical study. The hypothesis that technical inefficiency effects were not present in our sample $\left(\gamma=\delta_{0}=\delta_{1}=\ldots=\delta_{18}=0\right)$ was strongly rejected. Results suggest that technical inefficiency was significant for this sample.

Table 2. Test of hypothesis for model selection and for the parameter of inefficiency terms

\begin{tabular}{|c|c|c|c|c|}
\hline Null hypothesis & $\begin{array}{l}\text { Log likelihood } \\
\text { value }\end{array}$ & $x^{2}$ & $p$-value & Decision \\
\hline \multicolumn{5}{|l|}{ 1. Model selection } \\
\hline Full translog production function & -3522.147 & & & \\
\hline $\begin{array}{l}\text { Cobb--Douglas with neutral technical } \\
\text { change, } \mathrm{H}_{0}: \beta_{m k}=\beta_{t t}=\beta_{t m}=0\end{array}$ & -3799.734 & 555.173 & 0.000 & Rejected*** \\
\hline $\begin{array}{l}\text { Translog with neutral technical change, } \\
\mathrm{H}_{0}: \beta_{t m}=0\end{array}$ & -3535.696 & 27.097 & 0.000 & Rejected $^{* * *}$ \\
\hline \multicolumn{5}{|l|}{ 2. Inefficiency term } \\
\hline $\mathrm{H}_{0}: \gamma=\delta_{0}=\delta_{1}=\ldots=\delta_{18}=0$ & -3631.103 & 217.912 & 0.000 & Rejected $* * *$ \\
\hline
\end{tabular}

The null hypotheses that the inefficiency effects are not a linear function of firm characteristics variables $\left(\delta_{0}=\delta_{1}=\ldots=\delta_{18}=0\right)$ are also rejected at the $1 \%$ level of significance, which indicates that the joint effects of these explanatory variables on the inefficiency of production are significant, although the individual effects of one or more variables might not be statistically significant ${ }^{3}$.

The results of the simultaneous estimation of the stochastic frontier function and the inefficiency determination function are shown in Table 3. The null hypotheses that variance parameters $\sigma_{u}{ }^{2}$ and $\gamma$ are zero are rejected at the $1 \%$ and $10 \%$ levels of significance, respectively, meaning that inefficiency effects are stochastic.

\footnotetext{
${ }^{3}$ Because three observations have very low TE values lower than 0.01 , we checked the data and found that their output was extremely low, although input variables had high values. These data might be attributable to unexpected shocks or incorrect data. Therefore, we re-estimated the frontier by excluding these three observations. The results changed slightly.
} 
Table 3. Maximum-likelihood estimates of stochastic frontier and inefficiency function

\begin{tabular}{|c|c|c|c|c|c|}
\hline \multirow{2}{*}{\multicolumn{2}{|c|}{$\begin{array}{l}\text { Variable } \\
\text { Stochastic fronti }\end{array}$}} & \multirow{2}{*}{$\frac{\text { Coeff. }}{\text { total out }}$} & \multicolumn{3}{|c|}{ Parameter Standard e $t$-ratio } \\
\hline & & & \multicolumn{3}{|c|}{ function: Dependent variable } \\
\hline Constant & & $\beta_{0}$ & $5.6059 * * *$ & 0.4173 & 13.4323 \\
\hline Material & & $\beta_{1}$ & $-0.3074 * * *$ & 0.0620 & -4.9595 \\
\hline Energy & & $\beta_{2}$ & $0.5613 * * *$ & 0.0584 & 9.6163 \\
\hline Labour & & $\beta_{4}$ & $0.9493 * * *$ & 0.1013 & 9.3736 \\
\hline Capital & & $\beta_{3}$ & $0.1488 * * *$ & 0.0454 & 3.2789 \\
\hline$\tau$ (time trend) & & $\beta_{5}$ & -0.1751 & 0.1137 & -1.5400 \\
\hline Material $\wedge 2$ & & $\beta_{11}$ & $0.0945 * * *$ & 0.0044 & 21.2922 \\
\hline Energy $^{\wedge} 2$ & & $\beta_{22}$ & $0.0076^{* * *}$ & 0.0028 & 2.6567 \\
\hline Capital $^{\wedge} 2$ & & $\beta_{33}$ & $0.0075 * * *$ & 0.0025 & 2.9630 \\
\hline Labour^ ${ }^{\wedge}$ & & $\beta_{44}$ & $0.0571 * * *$ & 0.0114 & 4.9958 \\
\hline$\tau^{\wedge} 2$ & & $\beta_{55}$ & 0.013 & 0.0202 & 0.6436 \\
\hline Material * Energ & & $\beta_{12}$ & $-0.0761 * * *$ & 0.0064 & -11.8716 \\
\hline Material $*$ Capito & & $\beta_{13}$ & $-0.0327 * * *$ & 0.0051 & -6.4411 \\
\hline Material * labou & & $\beta_{14}$ & $-0.1181 * * y$ & 0.0112 & -10.5154 \\
\hline Material $* \tau$ & & $\beta_{15}$ & $0.0208 * *$ & 0.0103 & 2.0303 \\
\hline Energy * Capital & & $\beta_{23}$ & $0.0169 * * *$ & 0.0049 & 3.4685 \\
\hline Energy * labour & & $\beta_{24}$ & $0.0466 * * *$ & 0.0092 & 5.0385 \\
\hline Energy $* \tau$ & & $\beta_{25}$ & -0.0059 & 0.0103 & -0.5718 \\
\hline Capital $*$ labour & & $\beta_{34}$ & 0.0008 & 0.0079 & 0.1079 \\
\hline Capital $* \tau$ & & $\beta_{35}$ & 0.0035 & 0.0086 & 0.4062 \\
\hline Labour $* \tau$ & & $\beta_{45}$ & $-0.0294 *$ & 0.0169 & -1.7456 \\
\hline \multicolumn{6}{|c|}{ Inefficiency determination function: Dependent variable is $U_{i t}$ (technical inefficiency). } \\
\hline Constant & & $\delta_{0}$ & $0.7409 * * *$ & 0.1491 & 4.9673 \\
\hline \multirow[t]{8}{*}{ Industry dummy } & Textiles & $\delta_{1}$ & $-0.3166 * * *$ & 0.1203 & -2.6331 \\
\hline & Garments & $\delta_{2}$ & $-0.1906 * *$ & 0.0781 & -2.4389 \\
\hline & Shoes and Leather Products & $\delta_{3}$ & -0.1298 & 0.0897 & -1.4478 \\
\hline & Chemicals & $\delta_{4}$ & 0.0706 & 0.1092 & 0.6467 \\
\hline & Machinery & $\delta_{5}$ & $-0.2577 * *$ & 0.1033 & -2.4944 \\
\hline & Electronics & $\delta_{6}$ & -0.1533 & 0.1511 & -1.0149 \\
\hline & Auto-parts & $\delta_{7}$ & -0.1177 & 0.1087 & -1.0824 \\
\hline & Furniture & $\delta_{8}$ & $-0.1296 *$ & 0.0770 & -1.6830 \\
\hline \multicolumn{2}{|c|}{ Education level of principal manager } & $\delta_{9}$ & 0.0184 & 0.0126 & 1.4652 \\
\hline \multicolumn{2}{|c|}{ Working experience of principal manager } & $\delta_{10}$ & -0.0026 & 0.0018 & -1.4830 \\
\hline \multicolumn{2}{|c|}{ Foreign competition } & $\delta_{11}$ & -0.0819 & 0.0668 & -1.2254 \\
\hline \multicolumn{2}{|c|}{ Telephone } & $\delta_{12}$ & -0.0275 & 0.0239 & -1.1480 \\
\hline \multicolumn{2}{|l|}{ Internet } & $\delta_{13}$ & 0.006 & 0.0195 & 0.3062 \\
\hline \multicolumn{2}{|l|}{ Computer } & $\delta_{14}$ & $-0.0106 * * *$ & 0.0022 & -4.8979 \\
\hline \multicolumn{2}{|l|}{ Loan } & $\delta_{15}$ & -0.0205 & 0.0589 & -0.3478 \\
\hline \multicolumn{2}{|l|}{ Export } & $\delta_{16}$ & $-0.3656 * * *$ & 0.0640 & -5.7157 \\
\hline \multicolumn{2}{|l|}{ Capital import } & $\delta_{17}$ & -0.0712 & 0.0746 & -0.9542 \\
\hline \multicolumn{2}{|c|}{ Technology advantage } & $\delta_{18}$ & $-0.0634 *$ & 0.0366 & -1.7323 \\
\hline \multicolumn{2}{|c|}{ sigma-square } & $\sigma^{2}$ & $0.3429 * * *$ & 0.0163 & 21.0599 \\
\hline \multicolumn{2}{|l|}{ gamma } & $\gamma$ & $0.0656^{*}$ & 0.0459 & 1.4287 \\
\hline \multicolumn{2}{|l|}{ Log-likelihood } & & -3543.44 & & \\
\hline \multicolumn{2}{|l|}{ Mean efficiency } & & 0.8186 & & \\
\hline \multicolumn{2}{|c|}{ Number of obs. } & & 4032 & & \\
\hline \multicolumn{6}{|c|}{$\begin{array}{l}\text { Notes: } 1 \text {. According to Coelli et al. (2005) } t \text {-tests are used for testing hypotheses concerning individual } \\
\text { parameter, because unconstrained ML estimators are asymptotically normally distributed if the sample size is } \\
\text { large. We use a } t \text {-test because our sample size is large enough. } \\
2 \text {. Asterisks } * * *, * * \text {, and } * \text { respectively denote statistical significance at } 0.01,0.05 \text {, and } 0.1 \text { significance levels. } \\
\text { 3. Reference is the Food processing industry. }\end{array}$} \\
\hline
\end{tabular}


The estimated coefficients in the inefficiency determinant function are of particular interest in this study. Regarding the industry dummy, only Textiles, Machinery and Apparel are found to be more efficient than the Food processing industry (reference industry) at 1\%, 5\% and 10\% significance levels, respectively ${ }^{4}$. Even though the estimated coefficients for education level and working experience of the principal manager are not statistically significant, the signs of the estimated coefficients are consistent with a priori expectations, i.e., a higher education level and longer working experience of the principal manager have positive effects on technical efficiency. The foreign competition dummy is found to be not significant, but the positive impact is in line with the expectation that internationalization and international competition contribute to firm efficiency. Although communication methods such as the telephone and internet are expected to have a positive impact on efficiency, the estimated coefficients are not significant. The negative sign and a significant result for computers imply that a higher frequency of computer usage contributes to a firm's technical efficiency. Although the negative estimates for loan and capital import are also in accordance with expectations, they are not statistically significant. Subjective observations of interviewees about the technological advantage of their affiliated firm have a significant and expected sign. Finally, in line with a priori expectations, the export dummy has a strong positive effect on technical efficiency, which implies that export firms are more efficient than non-export firms.

Using Equations (5), (6) and (7), the annual percentage change of TEC, TC, TFPC were calculated for each firm in each pair of adjacent years. Table 4 shows the cumulative percentage changes of TEC, TC and TFPC. As presented in the table, TC shows greater contributions to TFPC than TEC does. Taken together, the results of SFA estimation suggest that the translog form is an appropriate specification for production function. Results show that technical inefficiency exists to a marked degree in the sample firms. Industrial dummies showed that textile, machinery and apparel industries are more efficient than the reference industry (food processing industry). Moreover, the estimation revealed that variables such as usage of PCs, exporting firm and technological advantages have significant impacts on efficiency. Finally an important finding here is that the greatest part of total factor productivity change was brought by technological change, although the contribution of technical efficiency change was rather small.

Table 4. Cumulative percentage change

\begin{tabular}{|cccc|}
\hline Year & TEC & TC & TFPC \\
\hline 2000 & 0.000 & 0.000 & 0.000 \\
2001 & 0.189 & 3.132 & 3.321 \\
2002 & 0.583 & 3.587 & 4.170 \\
\hline
\end{tabular}

${ }^{4}$ Here a negative sign of the coefficient to inefficiency means a positive impact on efficiency. 


\section{Determinants of TFP Growth Rates}

In this section, we examine the influences of firm's openness to their productivity using TFPC. To elucidate the effects of openness on TFPC, first we compare the averaged TFPC of more-open firms with that of less-open firms, as shown in Fig. 2.

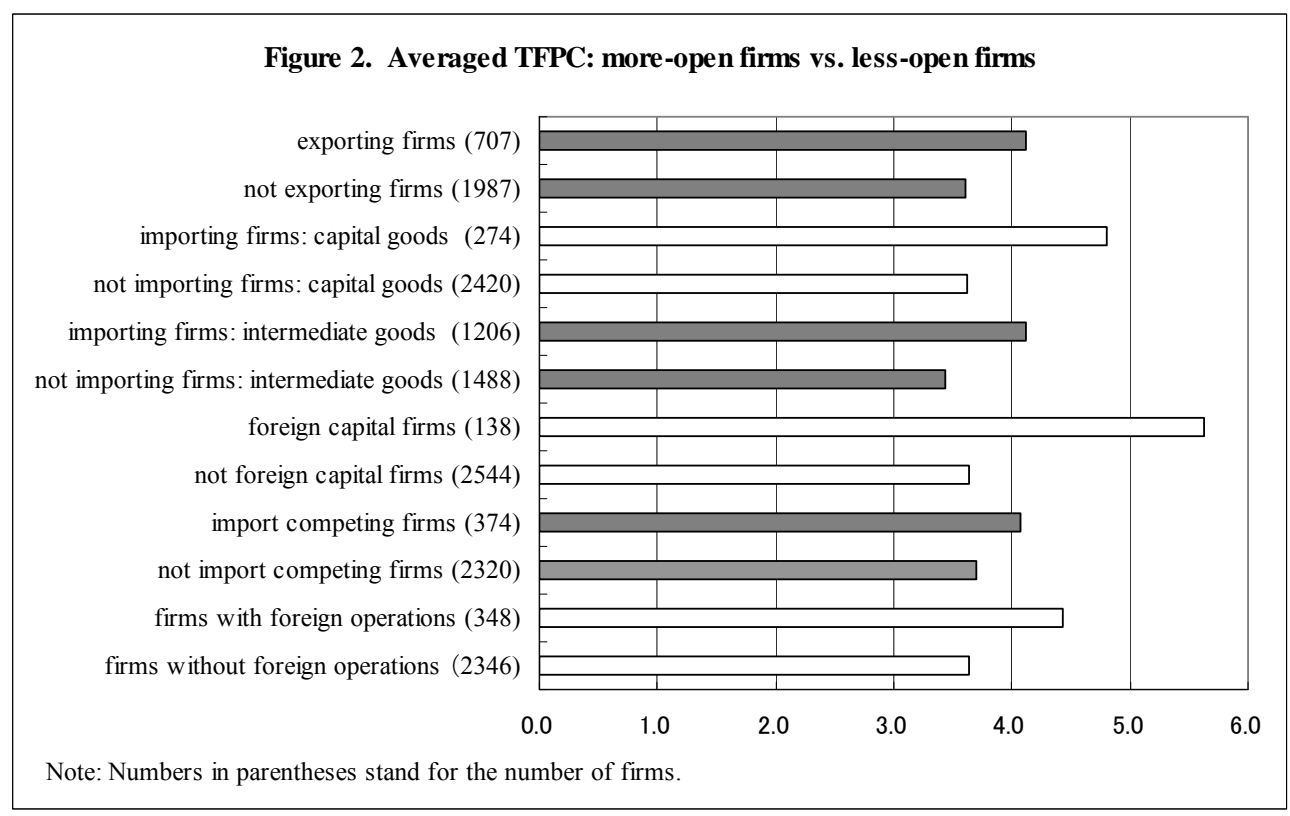

As expected, more-open firms have higher TFPC. Here, more-open firms are exporting firms, importing firms of capital goods or intermediate goods, foreign firms or foreign capital participant firms, firms confronting import competition and firms operating abroad. The results of the comparison explained above imply that openness plays an important role in improving firm productivity. In the following section, TFPCs of the sample firms are regressed on openness indicators and firm-specific explanatory variables. A list of variables is given in Table 5. 
Table 5. Descriptive Statistics

\begin{tabular}{|c|c|c|c|c|c|c|}
\hline Variables & Definitions & Obs & Mean & Std. Dev. & Min & Max \\
\hline TFPC & TFP growth rates estimated by SFA & 2694 & 3.7454 & 3.39331 & -16.956 & 36.7627 \\
\hline \multicolumn{7}{|l|}{ variables for openness } \\
\hline Exports & $\begin{array}{l}\text { Dummy variable that equals } 1 \text { for firms with direct exports }=1 \text {, } \\
\text { otherwise }=0\end{array}$ & 2694 & 0.26 & 0.44 & 0 & 1 \\
\hline Capital goods imports & imported capital goods/ total capital goods (\%) & 2694 & 6.48 & 22.29 & 0 & 100 \\
\hline $\begin{array}{l}\text { Intermediate goods } \\
\text { imports }\end{array}$ & imported intermediate goods /total intermediate goods $(\%)$ & 2694 & 11.04 & 20.59 & 0 & 100 \\
\hline Import competition & $\begin{array}{l}\text { Dummy variable that equals } 1 \text { for firms mainly competing } \\
\text { with imported products, and } 0 \text { otherwise }\end{array}$ & 2694 & 0.14 & 0.35 & 0 & 1 \\
\hline Foreign firm & $\begin{array}{l}\text { Dummy variable that equals } 1 \text { for firms with at least } 10 \% \text { of } \\
\text { capital owned by foreigners }=1 \text {, otherwise }=0\end{array}$ & 2694 & 0.05 & 0.21 & 0 & 1 \\
\hline Foreign operation & $\begin{array}{l}\text { Dummy variable that equals } 1 \text { for firms with foreign } \\
\text { operations, } 0 \text { otherwise. }\end{array}$ & 2694 & 0.13 & 0.34 & 0 & 1 \\
\hline Tariff reduction & $\begin{array}{l}\text { index of tariff reduction of each industries expressed by } \\
\text { deviation from the total average }\end{array}$ & 2694 & -0.05 & 0.20 & -0.39 & 0.26 \\
\hline \multicolumn{7}{|l|}{ control variables } \\
\hline Labour & Natural logarithm of the total number of full-time workers & 2694 & 4.03 & 1.13 & 1.79 & 8.77 \\
\hline Firm age & 2003 minus the year of establishment & 2694 & 19.02 & 16.48 & 1 & 110 \\
\hline Ttraining program & $\begin{array}{l}\text { Dummy variable that equals } 2 \text { for firms offering formal in- } \\
\text { house and outside training programs, } 1 \text { for either program and } \\
0 \text { otherwise. }\end{array}$ & 2692 & 1.03 & 0.83 & 0 & 2 \\
\hline Innovation & $\begin{array}{l}\text { Ranked from } 0 \text { to } 5 \text { where } 5 \text { is the highest level, and } 0 \text { is the } \\
\text { lowest level }\end{array}$ & 2694 & 1.65 & 0.96 & 0 & 5 \\
\hline Skilled worker & $\begin{array}{l}\text { Share of production skilled workers and professionals divided } \\
\text { by total workers }(\%)\end{array}$ & 2694 & 3.70 & 6.32 & 0 & 66.67 \\
\hline Non-production worker & Share of non-production workers divided by total workers (\%) & 2694 & 11.79 & 11.23 & 0 & 82.5 \\
\hline Industrial dummy & 9 industries: referenced by garments industry & 2688 & 5.11 & 2.67 & 1 & 9 \\
\hline State dummy & 13 states: referenced by Maranhão & 2688 & 4.59 & 3.22 & 1 & 13 \\
\hline Year dummy & referenced by 2000 & 2688 & 2001.5 & 0.50 & 2001 & 2002 \\
\hline
\end{tabular}

To investigate the effects of firms' openness on TFP growth more specifically, we define the determinant equation for total factor productivity growth. TFPC is regressed on variables as openness-related variables and other firm characteristics.

$$
T F P C_{i t}=\phi_{0}+H_{i t} \phi_{h}+F_{i t} \phi_{f}+\varepsilon_{i t}
$$

where $H_{i t}$ is a vector of explanatory representing firm $i$ 's openness and $F_{i t}$ is a vector of other fixed effects of firm $i$. We use the following variables to indicate openness: Export, Capital goods imports, Intermediate goods imports, Import competition, Foreign firms, Foreign operation and Tariff reduction of the affiliated industry (see definitions in Table 5). To capture other fixed effects, we introduce the variables of Labour (total number of workers), Firm age, Training program, Innovation (degree of activities for innovation), Skilled worker (share of total worker) and Non-production worker (share of workers for administration). To the estimation, we add dummy variables for Industry, State and Year. Because the tariff reduction index is measured by industry, we do not add an industrial dummy when Tariff reduction is included. In the following, we run OLS regressions with robust standard errors. 
Table 6. Determinants of TFPC, TEC, and TC in Brazilian manufacturing industries

\begin{tabular}{|c|c|c|c|c|c|c|}
\hline \multirow[b]{2}{*}{ Variables } & \multicolumn{6}{|c|}{ Dependent variable } \\
\hline & $\begin{array}{c}\text { TFPC } \\
(1)\end{array}$ & $\begin{array}{c}\text { TFPC } \\
(2)\end{array}$ & $\begin{array}{c}\text { TFPC } \\
(3)\end{array}$ & $\begin{array}{c}\text { TFPC } \\
(4)\end{array}$ & $\begin{array}{l}\text { TEC } \\
(5)\end{array}$ & $\begin{array}{l}\text { TC } \\
(6)\end{array}$ \\
\hline Exports & $\begin{array}{l}0.591 * * * \\
(0.144)\end{array}$ & $\begin{array}{l}0.653 * * * \\
(0.151)\end{array}$ & & & & \\
\hline Exports (t-1) & & & $\begin{array}{l}0.583 * * * \\
(0.146)\end{array}$ & $\begin{array}{l}0.628 * * * \\
(0.153)\end{array}$ & $\begin{array}{l}-0.051 \\
(0.083)\end{array}$ & $\begin{array}{l}0.624 * * * \\
(0.125)\end{array}$ \\
\hline Catital goods imports & $\begin{array}{l}0.021 * * * \\
(0.003)\end{array}$ & $\begin{array}{l}0.017 * * * \\
(0.003)\end{array}$ & $\begin{array}{l}0.020 * * * \\
(0.003)\end{array}$ & $\begin{array}{l}0.016^{* * *} \\
(0.003)\end{array}$ & $\begin{array}{l}0.016 * * * \\
(0.002)\end{array}$ & $\begin{array}{l}0.004 * \\
(0.002)\end{array}$ \\
\hline Intermediate good imports & $\begin{array}{l}0.008 * * \\
(0.003)\end{array}$ & $\begin{array}{l}0.009 * * * \\
(0.003)\end{array}$ & $\begin{array}{l}0.008 * * \\
(0.003)\end{array}$ & $\begin{array}{l}0.009 * * * \\
(0.003)\end{array}$ & $\begin{array}{l}0.001 \\
(0.002)\end{array}$ & $\begin{array}{l}0.006^{* *} \\
(0.003)\end{array}$ \\
\hline Import competition & $\begin{array}{l}-0.456 * * \\
(0.182)\end{array}$ & $\begin{array}{l}-0.351^{*} \\
(0.187)\end{array}$ & $\begin{array}{l}-0.468 * * \\
(0.183)\end{array}$ & $\begin{array}{l}-0.357 * \\
(0.187)\end{array}$ & $\begin{array}{l}-0.197^{*} \\
(0.116)\end{array}$ & $\begin{array}{l}-0.305 * * \\
(0.148)\end{array}$ \\
\hline Foreign firms & $\begin{array}{l}1.139 * * * \\
(0.309)\end{array}$ & $\begin{array}{l}1.044 * * * \\
(0.304)\end{array}$ & $\begin{array}{l}1.167 * * * \\
(0.310)\end{array}$ & $\begin{array}{l}1.079 * * * \\
(0.303)\end{array}$ & $\begin{array}{l}-0.266^{*} \\
(0.154)\end{array}$ & $\begin{array}{l}1.385 * * * \\
(0.288)\end{array}$ \\
\hline Foreign operation & $\begin{array}{l}-0.090 \\
(0.174)\end{array}$ & $\begin{array}{l}-0.083 \\
(0.178)\end{array}$ & $\begin{array}{l}-0.075 \\
(0.173)\end{array}$ & $\begin{array}{l}-0.075 \\
(0.178)\end{array}$ & $\begin{array}{l}-0.101 \\
(0.091)\end{array}$ & $\begin{array}{l}0.049 \\
(0.149)\end{array}$ \\
\hline Tariff reduction & & $\begin{array}{l}0.546^{*} \\
(0.314)\end{array}$ & & $\begin{array}{l}0.529^{*} \\
(0.314)\end{array}$ & & \\
\hline Labour & $\begin{array}{l}-0.861 * * * \\
(0.068)\end{array}$ & $\begin{array}{l}-0.773 * * * \\
(0.068)\end{array}$ & $\begin{array}{l}-0.863^{* * *} \\
(0.069)\end{array}$ & $\begin{array}{l}-0.770 * * * \\
(0.069)\end{array}$ & $\begin{array}{l}0.037 \\
(0.047)\end{array}$ & $\begin{array}{l}-0.910 * * * \\
(0.053)\end{array}$ \\
\hline Firm age & $\begin{array}{l}-0.008^{*} \\
(0.004)\end{array}$ & $\begin{array}{l}-0.003 \\
(0.004)\end{array}$ & $\begin{array}{l}-0.008^{*} \\
(0.004)\end{array}$ & $\begin{array}{l}-0.002 \\
(0.004)\end{array}$ & $\begin{array}{l}-0.006 * * \\
(0.003)\end{array}$ & $\begin{array}{l}-0.002 \\
(0.004)\end{array}$ \\
\hline Training program & $\begin{array}{l}0.074 \\
(0.086)\end{array}$ & $\begin{array}{l}0.082 \\
(0.087)\end{array}$ & $\begin{array}{l}0.083 \\
(0.086)\end{array}$ & $\begin{array}{l}0.091 \\
(0.087)\end{array}$ & $\begin{array}{l}-0.033 \\
(0.063)\end{array}$ & $\begin{array}{l}0.140^{* *} \\
(0.066)\end{array}$ \\
\hline Innovation & $\begin{array}{l}0.041 \\
(0.062)\end{array}$ & $\begin{array}{l}-0.013 \\
(0.064)\end{array}$ & $\begin{array}{l}0.049 \\
(0.062)\end{array}$ & $\begin{array}{l}-0.004 \\
(0.064)\end{array}$ & $\begin{array}{l}-0.020 \\
(0.043)\end{array}$ & $\begin{array}{l}0.067 \\
(0.048)\end{array}$ \\
\hline Skilled worker & $\begin{array}{l}0.042 * * * \\
(0.011)\end{array}$ & $\begin{array}{l}0.059 * * * \\
(0.011)\end{array}$ & & & & \\
\hline Skilled worker (t-1) & & & $\begin{array}{l}0.031 * * * \\
(0.011)\end{array}$ & $\begin{array}{l}0.049 * * * \\
(0.010)\end{array}$ & $\begin{array}{l}-0.007 \\
(0.006)\end{array}$ & $\begin{array}{l}0.035 * * * \\
(0.009)\end{array}$ \\
\hline Non-production worker & $\begin{array}{l}0.023 * * * \\
(0.006)\end{array}$ & $\begin{array}{l}0.030 * * * \\
(0.006)\end{array}$ & & & & \\
\hline Non-production worker (t-1) & & & $\begin{array}{l}0.017 * * * \\
(0.005)\end{array}$ & $\begin{array}{l}0.024 * * * \\
(0.005)\end{array}$ & $\begin{array}{l}-0.003 \\
(0.003)\end{array}$ & $\begin{array}{l}0.019 * * * \\
(0.004)\end{array}$ \\
\hline Constant & $\begin{array}{l}5.981 * * * \\
(0.856)\end{array}$ & $\begin{array}{l}4.518 * * * \\
(0.817)\end{array}$ & $\begin{array}{l}6.052 * * * \\
(0.865)\end{array}$ & $\begin{array}{l}4.532 * * * \\
(0.823)\end{array}$ & $\begin{array}{l}0.811 \\
(0.596)\end{array}$ & $\begin{array}{l}5.676^{* * * *} \\
(0.629)\end{array}$ \\
\hline Industry dummy & Yes & No & Yes & No & Yes & Yes \\
\hline State dummy & Yes & Yes & Yes & Yes & Yes & Yes \\
\hline Year dummy & Yes & Yes & Yes & Yes & Yes & Yes \\
\hline Number of samples & 2689 & 2689 & 2688 & 2688 & 2688 & 2688 \\
\hline R-Squared & 0.213 & 0.178 & 0.209 & 0.172 & 0.058 & 0.337 \\
\hline
\end{tabular}


The results of model 1 support the hypothesis that Exports, Capital goods import, Intermediate goods imports and Foreign firm increase TFPC. To export their products, the firms must produce internationally competitive goods with higher quality and at a lower cost, which require higher productivity. Firms that import capital goods and intermediate goods can benefit from advanced technologies that are embodied in these goods. Through direct investment or foreign capital participation, advanced technologies and modern managerial styles are transferred to domestic firms, which will improve their TFP.

However, contrary to those expectations, Foreign operation is not significant. Firms which answered 'yes' to the question 'Does your firm have holdings or operations in other countries?' are defined as foreign-operating firms with 1 for the variable of Foreign operation. Although the database has no information about countries in which the firms are operating, many Brazilian firms are known to operate in neighbouring countries, where high productivity and efficient management are not necessarily required to compete with firms in the host country market.

Import competition has a significant and negative sign. In theory, competition with imported goods is expected to present various incentives for domestic firms to increase productivity to survive severe import competition. However considering the recessive circumstances of the sample period after the currency crisis in 1999, it can be interpreted that import competition prevented the entry of new firms with high productivity or investment from introducing new technologies. In model (1), all industry dummies have significant coefficients at the one percent level. Model (2), which includes Tariff reduction instead of industry dummy, has a significant and positive sign. Because tariff reduction rates differ by industry, Tariff reduction can capture the industry fixed effects, which suggests that tariff liberalization can have positive impacts on industry productivity. Other variables such as Labour, Skilled worker and Non-production worker have significant impacts on TFPC as well.

According to Wooldrige (2002) ${ }^{5}$, we identified the suspected endogenous variables. Consequently, Exports, Skilled worker and Non-production worker were confirmed as endogenous variables, which are included in the equation with a one-year lag to avoid the biases caused by endogeneity. Endogeneity derives from the bidirectional causality between these variables and productivity. As presented in Table 6, despite the introduction of a one-year lag for these variables, models (3) and (4) yield very similar estimation results to those of models (1) and (2).

Because TFPC comprises TEC and TC, as discussed using Equation (7), we conducted regression analyses of model (5) for TEC and model (6) for TC. Regarding TEC, the explanatory power of variables for openness was considerably weaker. Although Capital goods

\footnotetext{
${ }^{5}$ First a suspected endogenous variable is regressed on all exogenous variables (reduced form). We obtain the estimated residual $\left(\hat{u}_{i t}\right)$. Then we run a regression of model (1) by OLS including the $\left(\hat{u}_{i t}\right)$ as an additional regressor and test the hypothesis that the coefficient of $\left(\hat{u}_{i t}\right)$ is equal to zero using a $t$ statistic. We conclude that the suspected variable is endogenous because $\left(u_{i t}\right)$ and $\left(\varepsilon_{i t}\right)$ are correlated if we reject the hypothesis.
} 
imports and Import competition have significant values for coefficients, similar to model (1)-(4), Foreign firm has a significant opposite sign and Exports has no significant relation to TEC. Therefore, for improving technical efficiency (moving the production point from inside the frontier to near or on the frontier), Capital goods imports can play an important role in introducing more efficient production methods that are expected to increase the technical efficiency of firms. Although it is difficult to interpret the results of foreign firms, results suggest that production methods and/or management style introduced by foreign firms are inappropriate for domestic firms as far as technical efficiency in production is concerned. Regarding the firm's fixed effects, explanatory variables except for Firm age are not significant, which suggests that other explanatory variables are needed. Contrary to model (5) for TEC, the explanatory power of model (6) is very high, as in the case of TFPC, which suggests that a major part of TFPC is attributable to TC. This inference is consistent with results of Table 4, which shows the cumulative percentage changes of TEC, TC and TFPC.

\section{Concluding Remarks}

This paper presented an investigation of the productivity of Brazilian firms based on firm level data of the Investment Climate Survey, provided by the World Bank. First, we calculated the growth rates of TFP of sample firms using stochastic frontier analysis, by which we estimated the translog production function and the determinant equation of technical efficiency simultaneously. Important findings are presented below.

(1) The TFP growth rate is the sum of changes in technical efficiency (TEC) and technological change (TC). The contribution to TFP growth rate of TC (3.587) is much greater than that of TEC $(0.583)$.

(2) Regarding determinants of TFPC, our regression suggests that openness generally led to improvement of productivity. Variables such as Exports, Capital goods imports, Intermediate goods imports and Foreign firm showed significant and positive impacts. By contrast, Import competition showed significant and negative influence on productivity. Foreign operation was not verified to have a significant relation with TFPC.

(3) Tariff reduction also showed a significant expected sign. The index of tariff reduction was calculated using changes in tariff rates during 1993-1999, which suggests that the tariff reductions in the 1990s had significant impacts on productivity even in the $2000 \mathrm{~s}$, when import liberalization had already been accomplished.

(4) With respect to technical efficiency (TEC), openness variables are not influential except Capital goods imports, which implies that the explanatory variables adopted here are inappropriate or that we omitted important variables that influence technical efficiency. More evidence is necessary to interpret the results related to TEC.

Other problems remain. Although we used a one-year lag for suspected endogenous variables, it is desirable to introduce an instrumental variable (IV) method, particularly for the 
relation between exporting and productivity. Regarding important omitted variables, we should have considered variables related to institutions and infrastructure.

Moreover, because the Investment Climate Survey provides firm-level data of many developing countries, it is possible to undertake comparative studies to elucidate the impacts of trade liberalization under globalization. However, because productivity must have been influenced not only by trade liberalization but also by other liberalization policies implemented in the same period, it will be an important task to investigate the impacts of trade liberalization controlling the effects caused by other policies.

\section{References}

Aigner, D., C. A. K. Lovell and P. Schmidt (1977) Formulation and estimation of stochastic frontier production function models, Journal of Econometrics, 6, 21-37.

Aw, B. Y., X. Chen and M. J. Roberts (2001) Firm Level Evidence on Productivity Differentials and Turnover in Taiwanese Manufacturing, Journal of Development Economics, 66(1), 51-86.

Battese, G. E. and T. J. Coelli (1995) A Model for Technical Inefficiency Effects in a Stochastic Frontier Production Function for Panel Data, Empirical Economics, 20, 325-32.

Battese, G. E. and G. S. Corra (1977) Estimation of a Production Frontier Model: With Application to the Pastoral Zone of Eastern Australia, Australian Journal of Agricultural Economics, 21, 169-79.

Caves, D. W., L. R. Christensen and W. E. Diewert (1982) "Multilateral Comparisons of Output, Input, and Productivity Using Superlative Index Numbers," Economic Journal, 9, 273-86.

Coelli, T. J., D. S. Prasada Rao, C. J. O'Donnell and G. E. Battese (2005) An Introduction to Efficiency And Productivity Analysis, 2nd ed., New York: Springer.

Constantin, P., D. L. Martin and B. B. de Ribera y Ribera (2009) "Cobb-Douglas, Translog Stochastic Production function and Data Development Analysis in Total factor Productivity in Brazilian Agribusiness," Anais, SIMPOI, 2009.

Ferreira, P. C. and J. L. Rossi Jr. (2003) "New Evidence from Brazil on Trade Liberalization and Productivity Growth," International Economic Review, 44, 1383-1405.

Good, D. H., M. I. Nadiri and R. C. Sickles (1997) "Index Number and Factor Demand Approaches to the Estimation of Productivity," in Pesaran, M. H. and P. Schmidt (Eds.), Handbook of Applied Econometrics: Vol.2. Microeconometrics, 14-80.

Hay, D. A. (2001a) "The Post-1990 Brazilian Trade Liberalization and the Performance of large Manufacturing firms: Productivity, Market Share and Profit," The Economic Journal, 111, 620-41.

Hay, D. A. (2001b) "A liberalização comercial brasileira após 1990 e o desempenho das grandes empresas industriais," Pesquisa e Planejamento Econômico, v. 30, n. 2, out. 2001.

Kalirajan, K. (1981) "An econometric analysis of yield variability in paddy production," 
Canadian Journal of Agricultural Economics, 29, 283-94.

Kumbhakar, S. C. and C. A. K. Lovell (2003) Stochastic Frontier Analysis, U.K., Cambridge University Press.

Meeusen, W. and J. V. D. Broeck (1977) "Efficiency Estimation from Cobb-Douglas Production Functions with Composed Error," International Economic Review, 18, 435-44.

Muendler, M. A. (2003) “Trade and Growth: The Case of Brazil," University of California, San Diego at http://econ.ucsd.edu/muendler/docs/brazil/muendler-brazil.pdf (accessed 10 January 2012).

Muendler, M. A. (2004) "Trade, Technology, and Productivity: A Study of Brazilian Manufacturers, 1986-1998," CESifo Working Paper, 1148.

Nazmi, N. and J. E. Revilla (2008) "Economic Efficiency and Growth: Evidence from Brazil, China and India," Research Paper No. 2008/86, United Nations University.

Nishijima, S. (2009) "Economic Liberalization and Productivity in Brazil: Empirical Analysis Using Firm Micro Data," Kokumin-Keizai Zasshi, 199, 1-18.

Pitt, M. M. and L. F. Lee (1981) "The measurement and sources of technical inefficiency in the Indonesian weaving industry," Journal of Development Economics, 9, 43-64.

Rossi, J. L. and P. C. Ferreira (1999) "Evolução da produtividade industrial brasileira e abertura comercial," IPEA,Texto para Discussão, n. 651.

Subramanian, U., W. P. Anderson and K. Lee (2005) "Measuring the Impact of the Investment Climate on Total Factor Productivity: The Case of China and Brazil," World Bank Policy Research Working Paper 3792.

Wooldridge, J. M., Econometric Analysis of Cross Section and Panel Data. Cambridge, MA: MIT Press, 2002, pp. 752. 